\title{
Oordeelsvorming rond de externe berichtgeving
}

\section{Samenvatting proefschrift*}

De verrichte studie omvat de analyse van enkele aspecten van de oordeelsvorming en besluitvorming rond de externe berichtgeving. De studie is als volgt opgezet. $\mathrm{Na}$ een schets van het algemene theoretische kader hebben wij getracht de discussies rond de formulering van visies op de doelstellingen van de jaarrekening en het jaarverslag met dit theoretische kader in verband te brengen. Op dezelfde wijze zijn de discussies rond de voor- en nadelen van regulering der externe berichtgeving geanalyseerd. Evenzo is ingegaan op enkele opvattingen van de verstrekkers en gebruikers van gegevens inzake de wenselijk te achten mate van openheid en zich bij de interpretatie van de jaarrekening en het jaarverslag voordoende problemen. Tevens hebben wij een empirisch onderzoek verricht naar de volgende aspecten: consistentie, consensus, functionele fixatie en enkele kenmerken van de wijze waarop mensen beslissingen nemen onder omstandigheden van onzekerheid. In de studie wordt ingegaan op de relevantie van het onderzoek voor drie groepen belanghebbenden bij de externe berichtgeving (de gegevensverstrekkers, de regelgevende instanties en de ontvangers van gegevens).

In hoofdstuk I van deze studie hebben wij een korte schets gegeven van enkele ontwikkelingen op het terrein der externe berichtgeving. Wij hebben geconstateerd dat over talrijke fundamentele vragen binnen het toch reeds oude vakgebied nog steeds zeer verschillend wordt gedacht. Een gevolg daarvan is dat vele ontwikkelingen die zich binnen het vakgebied voltrekken moeilijk met elkaar in verband zijn te brengen. Het vakgebied vertoont derhalve kenmerken van een wetenschap die aan het begin van haar ontwikkeling staat. Ook binnen deelgebieden van de externe berichtgeving bestaat weinig eenstemmigheid, zoals is gebleken uit een beschrijving van

\footnotetext{
* Zie: D. W. Feenstra, Oordeelsvorming rond de externe berichtgeving, Wolters-Noordhoff, Groningen, 1985. Het proefschrift vormt één van de uitkomsten van een onderzoek dat financieel gesteund is door de redactie van het Maandblad voor Accountancy en Bedrijfshuishoudkunde; het Limperg Instituut heeft bij de uitvoering van het onderzoek een coördinerende functie vervuld. Bij de opzet en uitvoering van het onderzoek is samengewerkt met Dr. J. H. R. van de Poel, die zich in het bijzonder op de oordeelsvorming rond de interne berichtgeving heeft gericht. Zie: J. H. R. van de Poel, Judgment and Control, WoltersNoordhoff, Groningen, 1986. Prof. Dr. J. L. Bouma heeft de voornoemde twee dissertatieonderzoekingen als promotor begeleid.
} 
de opkomst van een tweetal nieuwe gebieden. Zowel de 'Behavioral Accounting Research'-studies als de 'Human Information Processing'-studies blijken vele uiteenlopende vraagstellingen te omvatten. De ontwikkeling van probleemstellingen wordt daarbij niet gestuurd vanuit een bindend paradigma.

\section{Theoretisch kader}

In onze studie naar de oordeelsvorming en besluitvorming rond de externe berichtgeving hebben wij getracht een aanknopingspunt te vinden in enkele theorieën en begrippen zoals die voorkomen in de cognitieve psychologie (hoofdstuk II). Het desbetreffende vakgebied is volop in ontwikkeling; van een afgeronde cognitieve beslissingstheorie blijkt nog geen sprake te zijn, al zijn er in de literatuur diverse aanzetten te vinden. Wel hebben wij een globale schets gegeven van de structuur van een dergelijke theorie, waarbinnen de volgende elementen zijn aan te treffen:

1 Een individueel-psychologische en sociaal-psychologische systeembeschrijving van de beslissende personen of instanties. Wij hebben ons beperkt tot een weergave van enkele individueel-psychologische aspecten die daarbij van belang zijn, zoals:

$a$ kenmerken van het percipiërend vermogen van de mens;

$b$ de wijze waarop de menselijke rationaliteit zich bij de oordeelsvorming en besluitvorming manifesteert;

$c$ de wijze waarop de mens zich oordelen vormt en beslissingen neemt onder omstandigheden van onzekerheid.

2 Een modelmatige beschrijving van de taakomgeving. Wij zijn daarbij ingegaan op enkele methoden voor de meting van aspecten van de oordeelsvorming. De verscheidenheid in de bestaande methoden blijkt samen te hangen met de verscheidenheid in mogelijkheden tot structurering van problemen.

3 Regels met behulp waarvan beslissers een optimale gedragslijn proberen te selecteren. De toepassing van de beschikbare regels hangt niet alleen af van de gestructureerdheid van een probleem, maar tevens van allerlei individueel-psychologische kenmerken. Wij hebben enkele (heuristische) regels besproken die bij de besluitvorming worden gehanteerd.

Op tweeërlei wijze hebben wij getracht in deze studie gebruik te maken van enkele concepten en methoden uit de cognitieve psychologie. In de eerste plaats hebben wij geprobeerd enkele ontwikkelingen in de visies op de wenselijkheid van de regelgeving en op de doelstellingen van de jaarrekening en het jaarverslag te relateren aan de besproken begrippen en methoden uit de cognitieve psychologie (de hoofdstukken III en IV). In de tweede plaats hebben wij getracht enkele aspecten van de oordeelsvorming en besluitvorming in een verslaggevingscontext empirisch te onderzoeken (de hoofdstukken V en VI).

\section{Gegevensverstrekking en regulering}

Terzake van de opvattingen over het vakgebied der externe berichtgeving 
in haar algemeenheid hebben wij een tweetal stromingen onderkend (hoofdstuk III). Enerzijds is er de stroming die tracht vanuit de bestaande praktijk suggesties te doen ter verbetering van de externe berichtgeving. Anderzijds is er een stroming waar geprobeerd wordt op formele wijze vast te stellen welk stelsel van gegevensverstrekking als optimaal kan worden beschouwd. De eerstgenoemde stroming is voor de praktijk van de externe berichtgeving tot nu toe van grotere betekenis geweest dan de tweede stroming. Kenmerkend voor deze eerste stroming is de nauwe aansluiting van de analyses bij de problemen zoals die door de ondernemingsleiding worden gezien. In dat kader past geen onbeperkt rationeel handelende beslisser, integendeel. Het proces van de vormgeving van de externe berichtgeving door de ondernemingsleiding wordt ons inziens veeleer gekenmerkt door:

1 selectieve attentie en selectieve perceptie;

2 vage noties omtrent de effecten van de berichtgeving op de omgeving;

3 partiële analyses bij het nemen van beslissingen inzake wijzigingen in de externe berichtgeving.

De tweede stroming tracht een strikt formele benaderingswijze toe te passen in een realistisch institutioneel kader. In eerste instantie wordt in het kader van deze stroming uitgegaan van onbeperkte rationaliteit, waarbij geen plaats is voor verschijnselen als selectieve perceptie en heuristieken. In het kader van de in hoofdstuk III besproken reguleringsproblematiek hebben wij de informatie-economische benadering als te eng gekwalificeerd. Met name vanuit een sociologisch en politicologisch oogpunt hebben wij aangedrongen op uitbreiding van de theorie.

De volgende algemene conclusies werden door ons aan het einde van hoofdstuk III getrokken:

1 Zowel nationaal als internationaal valt er een opmerkelijke verruiming te constateren in zienswijze op de functies van de externe berichtgeving: van een financiële verantwoording voor een beperkte groep belanghebbenden naar het informeren in ruime zin van vele groepen geïnteresseerden. Voor de inhoud van de externe berichtgeving en de daarmee verband houdende regelgeving heeft dit ingrijpende gevolgen gehad. Het geschetste ontwikkelingsproces is tamelijk chaotisch verlopen.

2 De hoge abstractiegraad van het informatie-economische model heeft de betekenis ervan voor de praktijk van de externe berichtgeving sterk gereduceerd. Het model levert mogelijk een zinvol denkkader bij de analyse van verslaggevingsproblemen in een 'multi person setting', zoals bijv. de reguleringsproblematiek. De discussies terzake van de voor-en nadelen van regulering blijken nogal fragmentarisch te zijn geweest.

3 Er bestaat nog onvoldoende empirisch onderbouwd inzicht in de mate waarin en de wijzen waarop de ondernemingsleiding de externe berichtgeving terzake van de behaalde winst door middel van egalisatietechnieken tracht te beïnvloeden.

4 Uit een empirisch onderzoek onder 38 Nederlandse ondernemingen is gebleken, dat er in het algemeen gesproken in ruime mate niet-wettelijk verplichte gegevens met een openbaar karakter worden verstrekt. Indien ondernemingen over specifieke clusters bewust geen gegevens wensen 
te verstrekken, vloeit dit vooral voort uit de opvatting, dat men de concurrentie niet wenst te informeren.

\section{Opvattingen van de gebruikers}

Vervolgens hebben wij enkele aspecten van de oordeelsvorming bij het interpreteren van de externe berichtgeving door de gebruikers aan de orde gesteld (hoofdstuk IV).

Door middel van enquêtes en interviews hebben anderen vele malen onderzocht - nationaal zowel als internationaal - welke opvattingen er bij uiteenlopende groepen belanghebbenden bestaan. Vaak is daarbij geïnformeerd naar onvervulde wensen. In het algemeen gesproken blijkt het merendeel der gebruikers van mening te zijn: a) dat er voldoende openheid in de externe berichtgeving bestaat; b) dat er relevante gegevens vallen aan te treffen in jaarrapporten. Desondanks bestaan er bij alle onderzochte groeperingen nog onvervulde verlangens terzake van de gegevensverstrekking. Door middel van laboratoriumexperimenten kan worden nagegaan in hoeverre de gegevensverstrekking ten behoeve van de besluitvorming ook werkelijk functioneert. In het algemeen gesproken hebben vele onderzoekers geconstateerd dat er vaak een discrepantie bestaat tussen beweerde en feitelijke relevantie. Vooralsnog staat niet vast welke betekenis aan deze constatering dient te worden toegekend, mede gezien de veelal als onrealistisch te kwalificeren uitgangspunten van vele laboratoriumstudies. Onrealistische uitgangspunten blijken nogal eens voor te komen bij onderzoekingen naar relaties tussen besluitvormingsstijlen en de voorkeur voor bepaalde vormen van gegevensverstrekking, alsmede bij de in de studie besproken functionele-fixatie-studies.

In de praktijk van de externe berichtgeving blijken enquêtes en interviews meer weerklank te vinden dan de vaak nogal abstracte laboratoriumexperimenten. De door middel van enquêtes en interviews verkregen resultaten zijn namelijk eenvoudiger te interpreteren dan de onder gekunstelde en derhalve onrealistische omstandigheden verkregen laboratoriumonderzoekingen. Anderzijds maken vooral laboratoriumexperimenten een scherp inzicht mogelijk in de wijze waarop gebruikers feitelijk met gegevens omgaan. Uit theoretische modellen wordt het nut van gegevens weer op een andere manier afgeleid. Tot nu toe is evenwel nog niet aangetoond, dat bij de feitelijke besluitvorming de desbetreffende theoretische modellen worden gehanteerd.

\section{Empirisch onderzoek}

Door middel van een empirisch onderzoek, dat wij hebben uitgevoerd met medewerking san ervaren beleggingsanalisten en doctorale studenten, hebben wij in hoofdstuk $V$ geprobeerd na te gaan in hoeverre de oordeelsvorming van personen die beslissingen dienen te nemen op basis van gegevensverzamelingen, consistent is. Tevens hebben wij de mate van overeenstemming (consensus) tussen de beslissers onderzocht. De beschrijving van de opzet en de uitkomsten van het onderzoek wordt voorafgegaan 
door een beschouwing over de relevantie van de probleemstelling voor de verstrekkers van gegevens, voor de regelgevende instanties en voor de gebruikers van gegevens. In het algemeen gesproken hebben wij geconcludeerd, dat op voorhand niet valt aan te geven op welke wijze de drie genoemde groeperingen in een concreet geval zullen reageren op een bij de interpretatie van financieel-economische gegevens eventueel voorkomende gebrekkige consistentie en consensus bij de gebruikers van gegevens.

Het empirisch onderzoek is door ons uitgevoerd in de vorm van een experiment waarbij in eerste instantie aan de proefpersonen wordt gevraagd de aandelen van een vijftal ondernemingen, na kennisneming van de inhoud van een gegevensverzameling, te ordenen naar afnemende mate van 'kwaliteit'. Tevens werd de proefpersonen gevraagd aan te geven welke factoren naar hun mening de 'kwaliteit van een aandeel' bepalen. Het begrip 'kwaliteit' treft men aan in het vakgebied financiering, waar het met name in het kader van beleggingsbeslissingen wordt gehanteerd. Het desbetreffende deel van het onderzoek is opgezet ter verkrijging van factoren die in de hiërarchische structuur van de methode-Saaty kunnen worden geplaatst.

Wij hebben vervolgens het begrip consistentie geoperationaliseerd met behulp van de in het kader van hoofdstuk II beschreven methode-Saaty. De methode-Saaty is een multicriteria-methode die kan worden aangewend voor het oplossen van problemen waarbij kwalitatieve en kwantitatieve aspecten van belang zijn. De methode leidt onder meer tot de berekening van een consistentie-ratio (CR), zijnde een kwantitatieve maatstaf voor de transitiviteit van de oordeelsvorming. Onze proefpersonen bleken in het algemeen gesproken moeite te hebben met het scoren van een redelijk te achten consistentie-ratio. In hoeverre deze resultaten afbreuk doen aan de door anderen in het algemeen gevonden relatief hoge mate van consistentie, valt niet scherp aan te geven, ten gevolge van verschillen in de wijze van meting van het begrip consistentie (methode-Saaty versus Lens-Modelanalyses en ANOVA-studies). Nader onderzoek naar de mate waarin de verschillende methoden tot dezelfde conclusies leiden lijkt ons gewenst. De wenselijkheid hiervan volgt ons inziens uit de constatering van de beperktheid van Lens-Model-analyses en ANOVA-studies. Dergelijke analyses immers vergen scherp gestructureerde probleemstellingen, waarbij op grond van een gering aantal onafhankelijke variabelen ('cues') vele malen een voorspelling wordt gedaan of een beslissing wordt genomen. Zoals eerder werd gesteld in hoofdstuk II kunnen vele in de praktijk voorkomende problemen niet in een dergelijk keurslijf worden geperst.

Opvallend is voorts het door ons gevonden significante verschil tussen de CR-waarden van studenten en beleggingsanalisten. De studenten bereikten, gemiddeld gesproken, significant betere scores dan de beleggingsanalisten. Op grond van hetgeen uit de literatuur bekend is over de wijze van denken en de werking van het geheugen bij experts, zou men juist verwachten dat de beleggingsanalisten beter scoren dan de studenten. In de studie hebben wij enkele mogelijke verklaringen gegeven van de door ons gevonden resultaten. 
Terzake van het verschijnsel consensus hebben wij in hoofdstuk II reeds gesteld, dat uit het tot nu toe door anderen verrichte onderzoek geen eenduidig beeld naar voren komt: meermalen is een hoge mate van consensus aangetoond, ten minste even vaak een lage mate van consensus. Ook hier geldt, dat bij de analyse gewoonlijk Lens-Model-analyses en ANOVAstudies zijn verricht, waardoor een adequaat referentiepunt voor onze onderzoekresultaten ontbreekt. De mate van consensus tussen onze proefpersonen bleek redelijk te zijn, zowel terzake van het aangeven van kwaliteitsbepalende factoren, als terzake van de rangordening van fondsen. In het onderzoek hebben wij vrijwel steeds een significante mate van consensus tussen de proefpersonen binnen de diverse groepen gevonden, zowel met betrekking tot de door de proefpersonen vermelde ordeningen, als met betrekking tot de ordeningen berekend volgens de methode-Saaty.

In het in hoofdstuk VI beschreven empirisch onderzoek, dat wij eveneens in de vorm van een experiment hebben uitgevoerd, is in eerste instantie nagegaan in hoeverre bij de proefpersonen functionele fixatie (FF) kan worden vastgesteld. Dit verschijnsel kan leiden tot het niet correct interpreteren van gegevensverzamelingen en vervolgens tot het nemen van verkeerde beslissingen. De verstrekkers van gegevens kunnen maatregelen nemen ter vermindering van de kans op FF; het is evenwel niet uitgesloten dat zij trachten te profiteren van $\mathrm{FF}$. Ook regelgevende instanties kunnen maatregelen nemen ter vermindering van de kans op FF. Op voorhand staat niet vast hoe deze drie groeperingen in concrete gevallen zullen reageren (zie ook de in dit verband gemaakte opmerkingen bij het onderzoek dat in hoofdstuk $\mathrm{V}$ is beschreven).

Het desbetreffende onderzoek is, evenals het voorgaande, uitgevoerd met medewerking van ervaren beleggingsanalisten en doctorale studenten. De proefpersonen moesten koersvoorspellingen afgeven na ontvangst van bepaalde gegevensverzamelingen. In essentie draaide het onderzoek om de vraag in hoeverre koersvoorspellingen al dan niet veranderen, gegeven de op een specifieke wijze gemanipuleerde gegevensverzamelingen. De in het onderzoek betrokken manipulaties hebben betrekking op de wijze waarop belastingen naar de winst in de jaarrekening zijn verwerkt, alsmede op de door ondernemingen gehanteerde waarderingsstelsels. De resultaten van het onderzoek zijn in strijd met die gevonden in een soortgelijk onderzoek, zoals dat werd uitgevoerd door Abdel-khalik en Keller (1979). In het algemeen gesproken hebben wij geen steun kunnen vinden voor de functionelefixatie-hypothese.

In ons onderzoek hebben wij voorts enkele vraagstellingen opgenomen ter toetsing van verschillende door Swieringa et al. (1976) geformuleerde hypothesen. Het onderzoek was in het bijzonder gericht op de vraag in hoeverre onze proefpersonen in eenvoudige probleemsituaties statistisch gezien correcte beslissingen weten te nemen. In enkele gevallen kon het bestaan van het zogenaamde representativiteitsverschijnsel niet uitgesloten worden geacht. Opvallend was, dat wij geen significante verschillen tussen de groep beleggingsanalisten en de groep studenten hebben kunnen vaststellen. 